ABSTRACT

CC BY-NC-ND

\title{
Mari Mutare
}

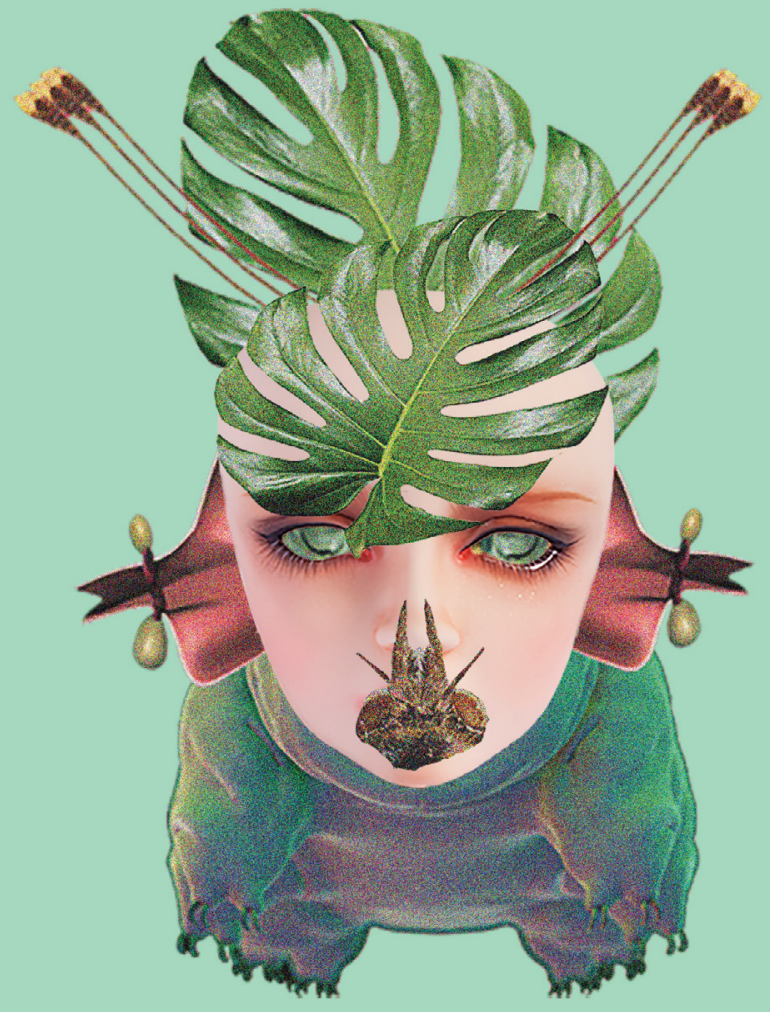

\section{MARIMUTARE: SPECULATIVE DESIGN AND} MANimutore is an experimact wiC and digital ornaments based on the Green Man which seeks to transcend human exceptionalism

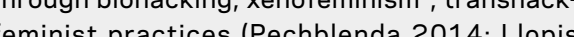
2015) and speculative design. The Gri Leen Basford 1978) is a carved, leafy head ornament tepresenting a pagan cult from the natural world. Iit a symbiotic ecological assemblage (Margulis queer desire to re-wild culture (Gibsen 2010 ) in search of more intimate interdependencies with nature (Frèger 2016). 


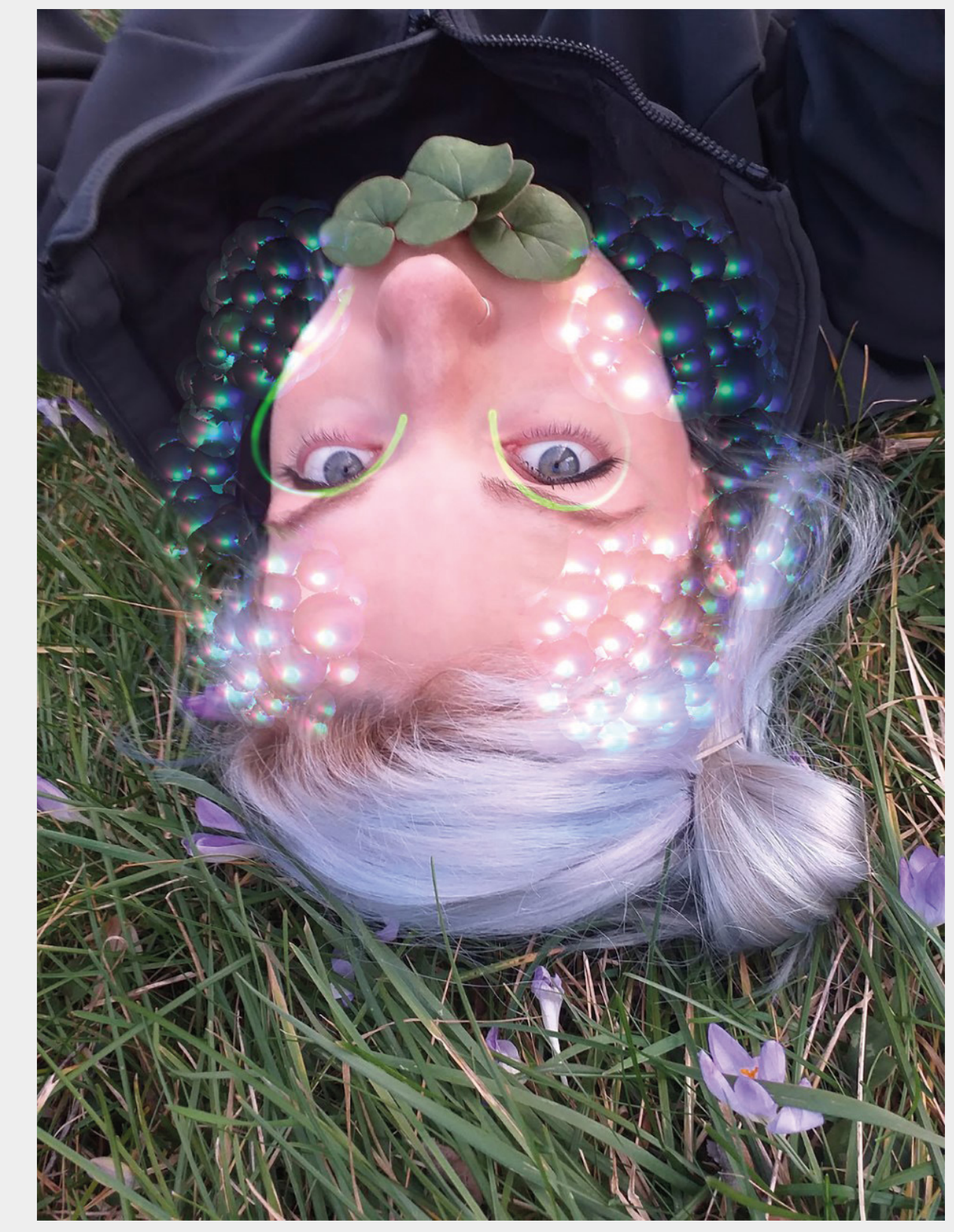
Within a context of biotechnological acceleration, Mari mutare is based on accessibility and significance of the tools to which we have access that have
three fundamental aspects. First, the power of critical speculative design emerged with the "do it yourself" biology movement (DIYBio) and biohacking
and science fiction a as possible influences of an alternative, queer and femand science fiction'2 as possible influences of an alternative, queer and fem- (Delfanti 2011; Kera 2014), which have fostered an increase of transdisciinist post-anthropocentric social imaginary. Second, the appropriation of plinary projects (Thacker 2005; Berger et al. 2020) and influenced the way biotechnological knowledge for non-biomedical use by designers and artists.
And, third, the experimentation with biological matter from one's own body think, work (Lorenzo 2016) and do design research (Milyazaki and
He21). to question one's own subjectivity. In the 1990s, bioartists (Davis 1996; Kac 1999) framed the fields of tissue When it comes to contextualising the project, it is worth mentioning that engineering (Catts and Zurr 2002; Cachat et al. 2018), biopolitics (Da Costa design has abandoned its linear progressivity to embrace the amalgam of and Philip 2008, 18), synthetic biology (Myers 2015, 125) and speculative disciplines, confronting the end of the Anthropocenes that places us, hu- design (Dunne and Raby 2013). By extension, the world of art, activism and
inss, at the centre of the cosmos (Crutzen 2002: 2016). The resulting new
global politics (Chardonnet 2016) initiated research at the intersection of ecological thinking (Hörl 2013; 2018, 151) and the material twist affecting media living organisms and technology. Artists and researchers such as feminist theory urge us to immerse ourselves in a posthuman (Braidotti2013; Mary Maggic address new becomings focusing on transhackfeminist bio2016, 18) and cyborgian (Haraway 1985, 7) world. This world is inhabited practices revolving around self-experimentation: with hormones -Houseby a multiplicity of agencies (Haraway 2003; Tsing 2012) that interlace in wives Making Drugs, by Fem Tour Truck, 2018- mushrooms -Becoming with

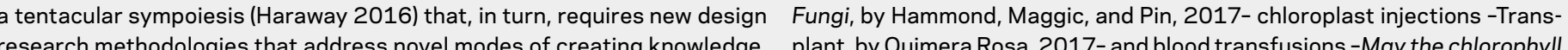
response-abilities and interspecies intra-actions (Barad 2014).

As technology expands our ability to shape objects and environments, the

progress of biosciences has added a more diverse palette available to design:
living matter (Elfick and Endy 2014, 9). It is important to highlight the greate

TEMES DE DISSENY \#37 plant, by Quimera Rosa, 2017- and blo
be with/in you, by Quimera Rosa, 2017-

PICTORIAL of one's own "otherness" and with becoming people who are a little less us and of the Forest, the expropriation of land), the extraction of natural and human alittle more other. In short, a person who is althle lesshuman andabit more resources, colonisation, he delegitimisation of non-scientific knowledge plant he. Melt the de

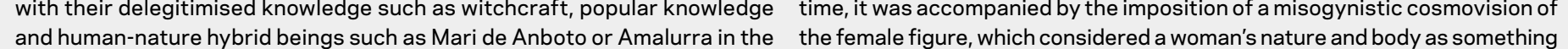
Basque Country (Barandiaran 2007; Ortiz-Osés 2007); the Wildermann, Les that could be expropriated and violated (Federici 2013).

Sauvages and the Tsaagäta in the Swiss Alps (Lajoux 2016); Les Feuillus or ''Homme Vert in France; and the Green Man or Tree Man in Great Britain
(Anderson 1990, 114; Araneo 2006).

1978; Gibson 2016) acts, in a certain simple fact that it is the most documented example. The figure, characterised by vines creeping through its body and the skin of an anthropomorphic
being, could be found throughout Europe from the 1st century B.C. At first being, could be found throughout Europe from the est century B.i. A t first
it was an image of pagan faith that later ended up being appropriated by the Church, and its representations were especially numerous during medieval times (Hardin 1998; Hayman 2010). This human-plant hybrid can be seen as a symbolic precursor to the work of several contemporary artists who also
work with plants and are the inspiration for this project.5 Furthermore, the Green Man evokes a tension between the "loss" of sovereignty over nature
and the lack of belonging to it. This could be due to an obsolete Cartesian and the lack of belonging to it. This could be due to an obsolete Cartesian
vision, which favours the man-nature dichotomy, and to the binary thought this reasox Mropiated and vilated (Federti 2013). mplications of the appropriation of our own body and bioautonomy as a way Wetween hacker philosophy and biopractices based on xenofeminism, and ohacker philosophy and transfeminism related to the creation of a "new (1) 866]; Bollier and Helfrich 2015; Dyer-Witheford 2007: Schantz 2013). the one hand, xenofeminism r reimagines the emancipatory potential of (t) he biohacker philosophy also addresses the appropriation of scientific uenced by experimentation with one's own body. It is also worth mentioning at the entire research process is found within a delicate balance between he ethics of manipulating life and the right to design for non-biomedical provoked by modernity (Latour 2014) and the scientific revolution. This rev- ambiguous ethics as well as strategies for navigating its policies.

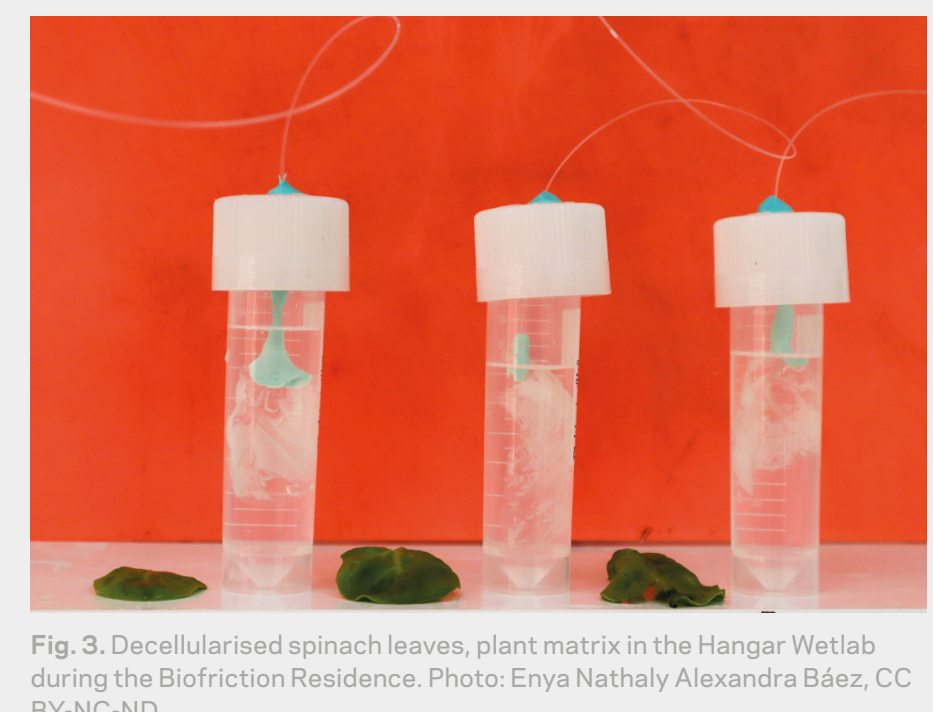

DECONSTRUCTING HUMAN EXCEPTIONALISM

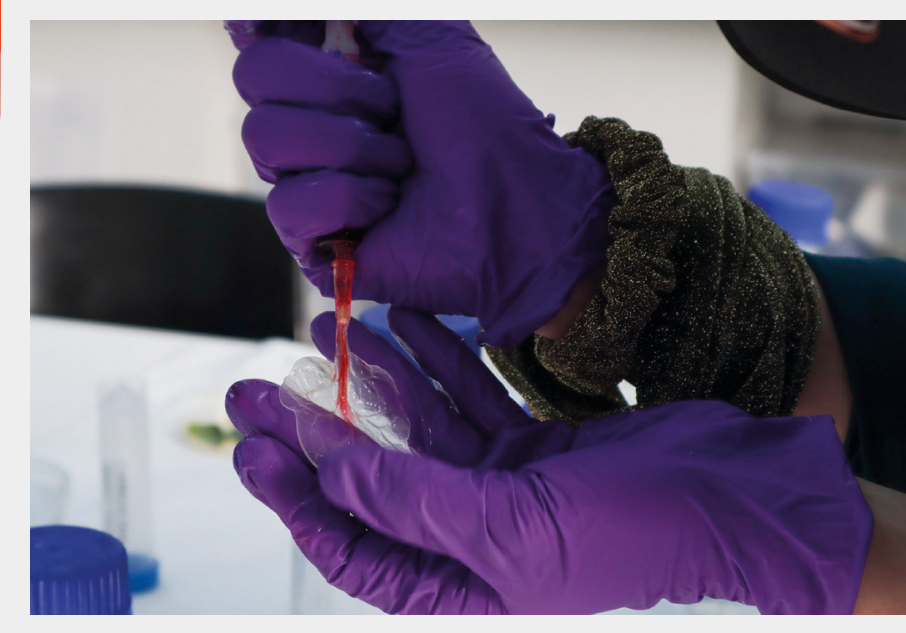

objective of Mari mutare is to question human exceptionalism and influwe have about ourselves, otherness and in vulnerable affects between the triad human, more-than-human and the technologies that interlace them (Haraway 2008). To do this, the process relies At the core of the practice for this project is the question of subjectivity tacit knowledge and the inherent tension between subject and researcher. How will prosthetics affect our subjectivity? Will they provoke sensory changes in the perception of the humanist self that challenge anthropological diffeV.LORENZC 


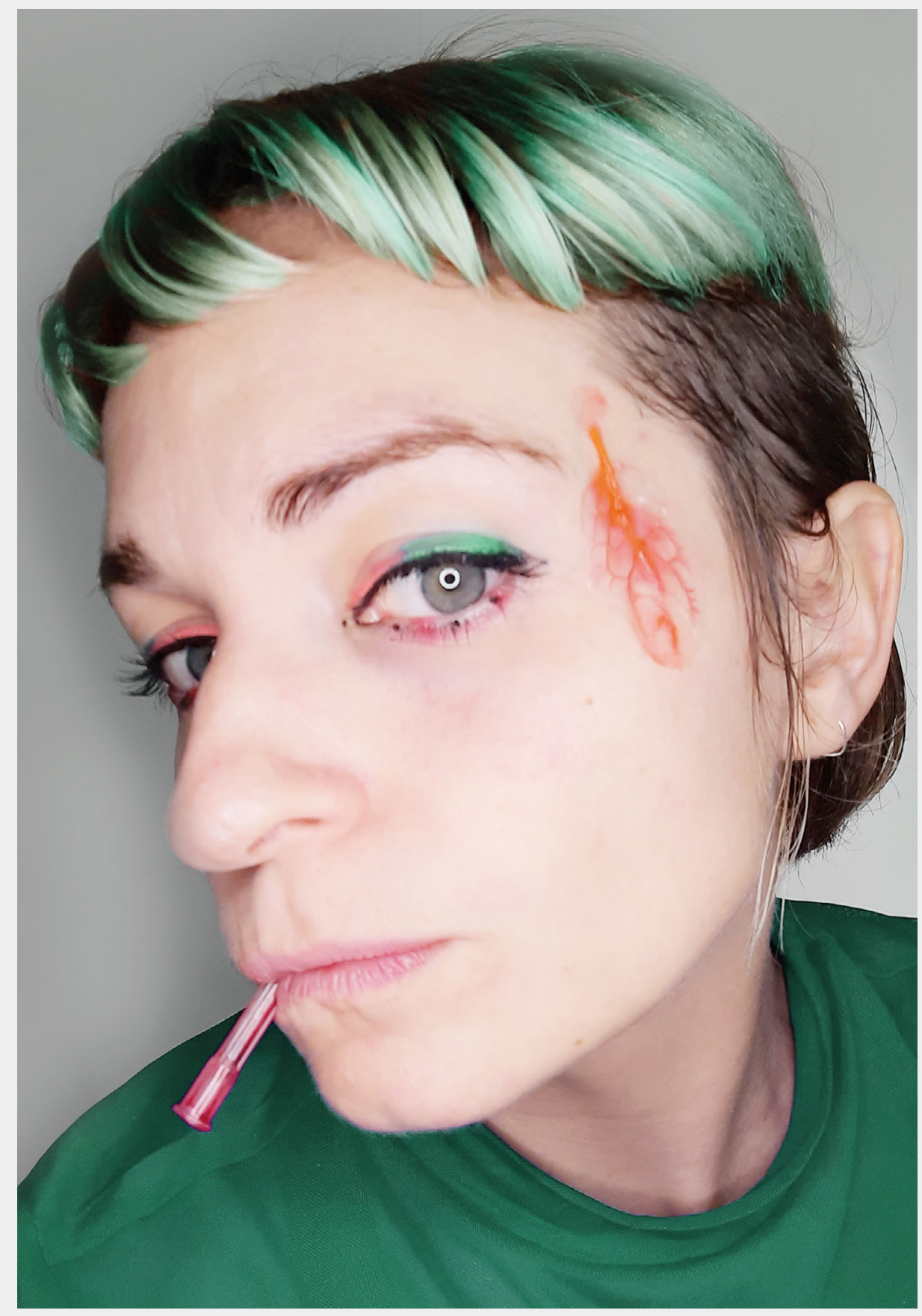

To explore the question of subjectivity, experiments were carried out with a methodology focused both on tacit knowledge and on the inherent tensions between the subject and researcher and the epistemic object. These tensions posits that the implantation of an "alien" tissue would affect the bodily subject, asserting the idea that individuality (the root of subjectivity) arises from the pre-reflexive experience of sometensen 2017) It is important to mention that xenotransplantation is is legal in Switzerland or Europe, therefore a speculative realism approach is required (Brassier 2008). For this task the transdisciplinary spectrum between design, art, politics, philosophy and

PICTORIAL

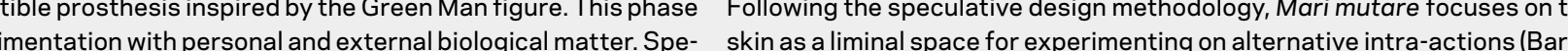
cludes experimentation with personal and external biological matter. Spe--
skin as a liminal space for experimenting on alternative intra-actions (Bara
fically, it involves spinach and my skin (or flesh). In the first phase, a spinach
and Kleinman 2012) between human and plant cell tissue. In turn, this limin as detergent and bleach in order to clean all the plant cell walls. An alternative
to detergent - replacing it with warm bleach and, in turn, the bleach with white vinegar - is currently being tested as well. After being decellularised, the

nce in the laboratory, tacit knowledge comes into play in thinking-with and doing-with the Petri dish as an epistemic (open, undefined) object (Rheinspinach leaf is used as a biocompatible plant matrix to support 3D growth berger 1997). In this case, the epistemic object is made up of an unstable,
of human skin cell tissue. To do this, two options were considered: a scarifi- cultural and ecological assembly of plant and human cells, combined and
cation cation ritual where the skin extracted during the process is recovered, and grown ind 作 will be grown with serum drawn from my blood. As it i i difficult to get our own ontological unfolding of the result formed by human-plant cell tissue and

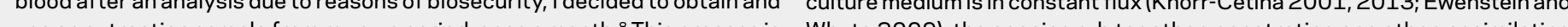

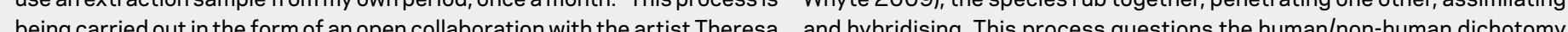
Schubert in her studio in Berlin. and argues against the who view que is generated during the closure process (Austin and Darso 2006): from the epistemic object (the Petri dish) to the boundary object, which is in fact the completed blocompatible prosthesis. In the losing process, the "echnical

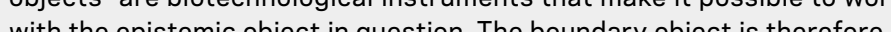
stable, closed and defined biocompatible prosthesis, which could enable us to communicate ideas that are ready to be shared between the communities of design practice and the general public.

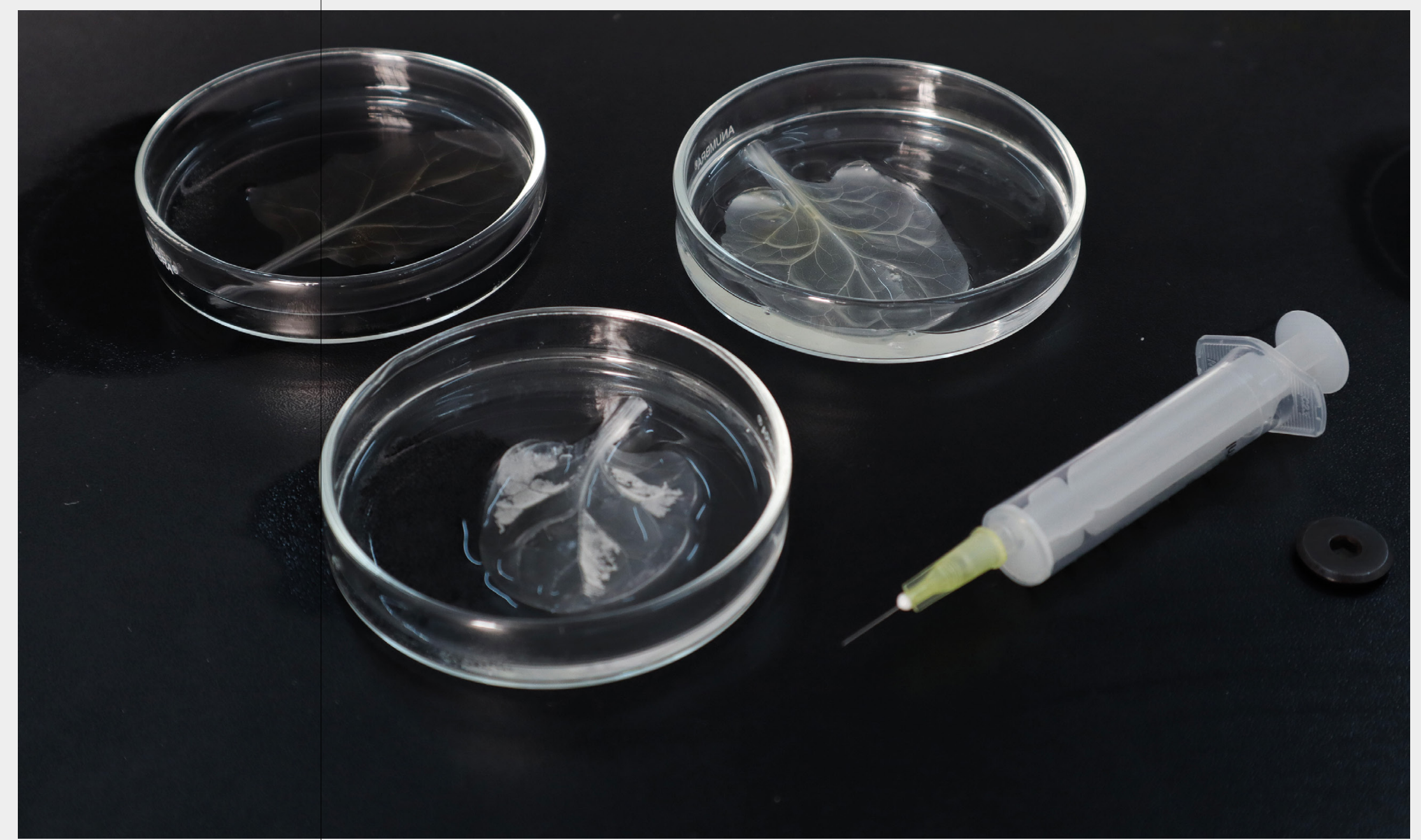




\section{Experiments}

Design experiment inspired by the "Green Ma of a human-vegetal hybrid that adresses the human-nature dichotomy established after

Plant Human Tech.

C 0

$\overline{\text { Experiment 1 }} \overline{\text { Experiment } 2} \overline{\text { Experiment } 3}$ $\begin{array}{ll}\text { Tissue culture } & \begin{array}{l}\text { Geene edit } \\ \text { cell hybrization brid-living hy }\end{array} \\ \text { cell } & \text { symament }\end{array}$ cell hybridization brid ornament
human-vegeta

Researcher Biohacker-Space

Laboratory

B

Collaboration Collaboration Collaboration Structure 1 Structure 2 Structure 3

Dissemination

Design and coordination of events among communities of practice in alternative spac cultural hubs. and cross-boundary interaction between multiple actors.

Researcher Public

\section{( $) 0$}

Workshop 1 Workshop 2 Workshop 3 Gene edit \& cell Semi-living $\begin{array}{ll}\text { hybridisation } & \text { hybrid } \\ & \text { ornament }\end{array}$ ornament,
limb design

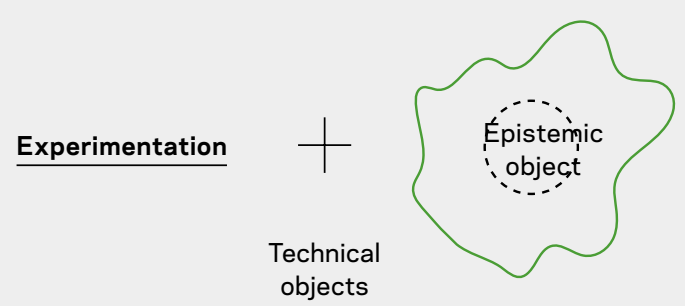
\begin{tabular}{l|l}
$\begin{array}{ll}\text { Tacit knowledge } \\
\text { learning by doing }\end{array}$ & $\begin{array}{l}\text { Explicit knowledge } \\
\text { learning by sharing }\end{array}$
\end{tabular} 个 r Unfolding ontology dyadic; partially express in various instantiation allows knowledge work over time.

Defined, static, dyadic, instrument, fixed, ready to
use by the expert subject.
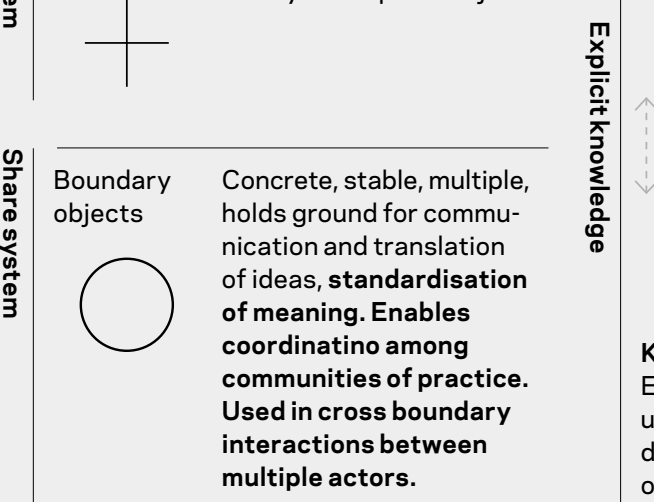

Tacit knowledge

(a) new knowledge-making territory.

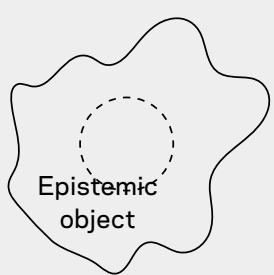

Unfolding ontology

Undefined, influx and
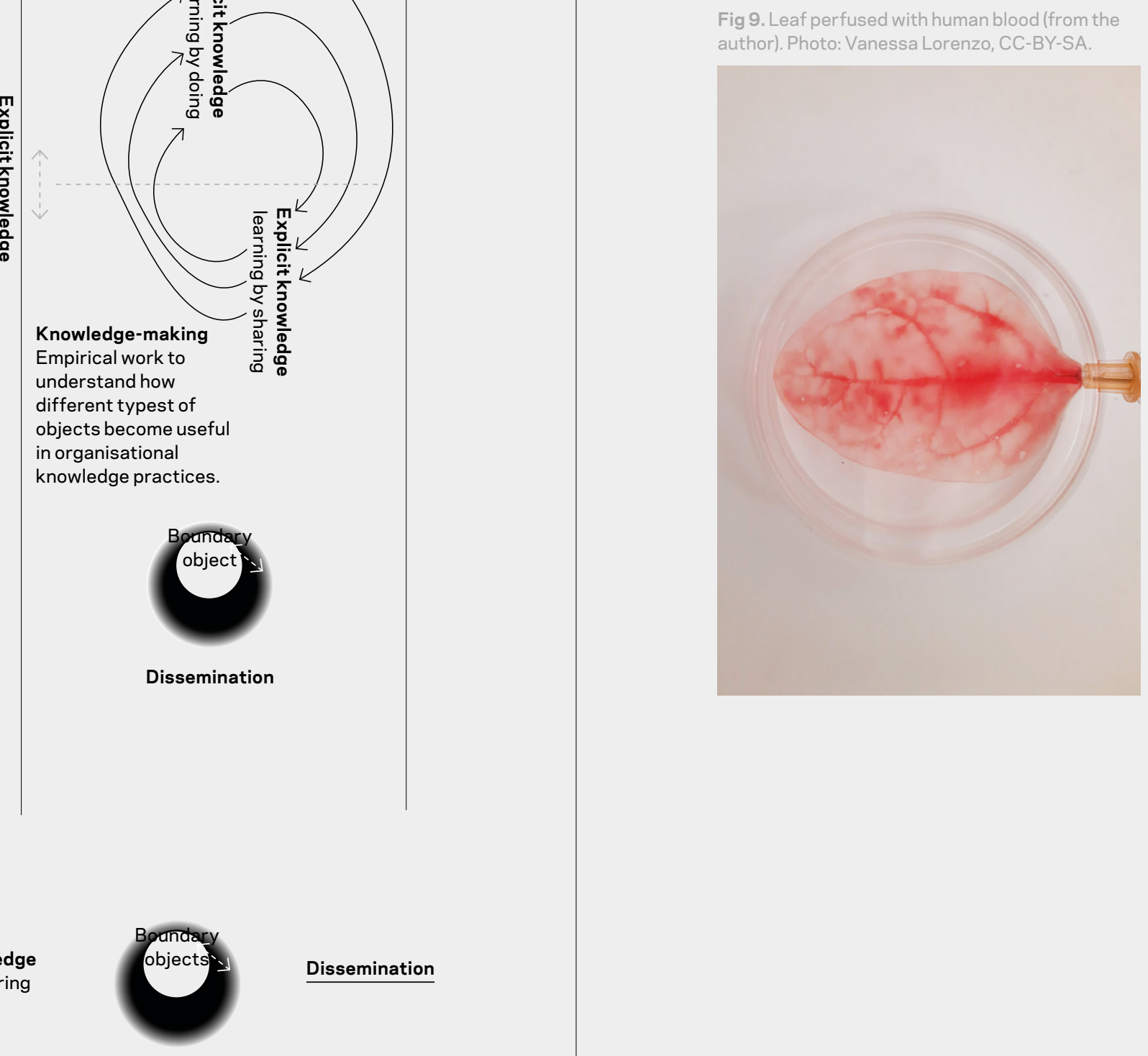

Dissemination

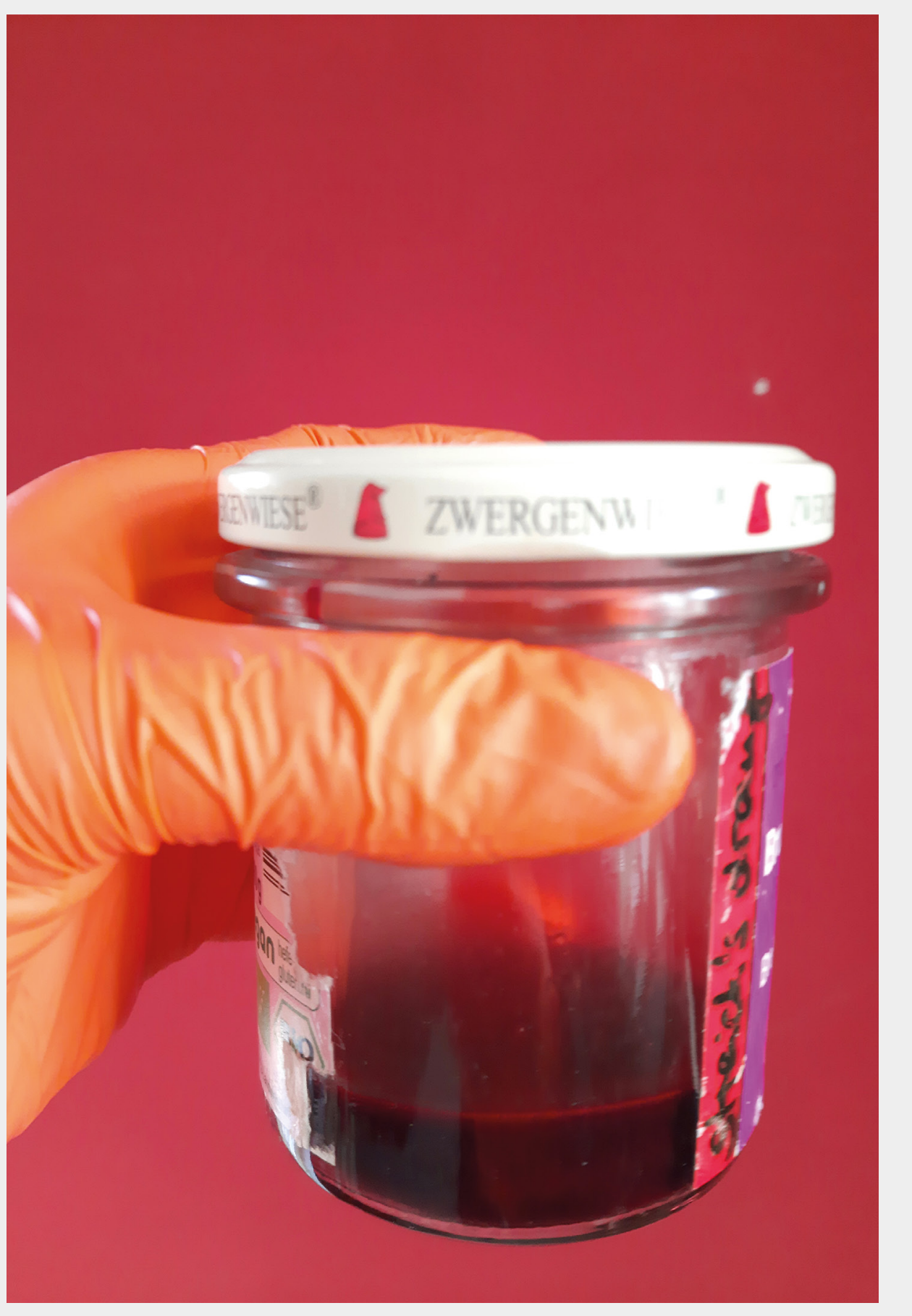

OPEN CONCLUSION

Perhaps every becoming-plant is a form of resistance with political effects ${ }^{9}$ to integrate it into ou being Pho transcend our skin beyond gender, species or living kingdom, we pass through the membrane that separates the self from our environment and from the other. We can speak of ontological uncertainty, bipolarity, schizophrenia ourselves, referring to Zoe and the equalisation of species the reminder the Moreover, it could be said that the project is also a transition from ornament to organ, passing through the prosthesis. In general terms, and taking into account that the research and experiments are still in progress, it can be we can already perceive an alteration of the body. The experience of the self and the other changes as a part of our body leaves, or is extracted, and becomes something alien, the beautiful distance between me and the other, between me and the environment. Ultimately, this experience affects how

V. LORENZO 


\section{BIOGRAPHY}

Vanessa Lorenzo Toquero
Hybridoa, Hackuarium

Wessa Lorenzo creates hybrid media ecologies that incorporate people who are considered more-than-human, as well as the (bio)technologies th ghting the agency of the more-than-human. Trained as an industrial design engineer and digital media designer, Vanessa is critically engaged with technology and seeks to enable strange sympathies between differen species, thus supporting post-anthropocentric futures. Originally from
Bilbao and currently based in Lausanne, Vanessa has conducted collaborative workshops that she has exhibited internationally, focusing on the radical poetry of the more-than-human. Her practice thrives on hacker-artist communities working in alternative spaces to

\section{ENDNOTES}

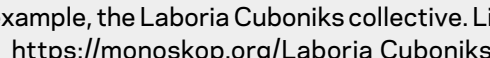

ttps://monoskop.org/Laboria_Cuboniks (Koetley and Tenga 2016) and Hopepunk (Haraway 2016
are notable influences for this project and these works foster new ways of thinking and doing with other beings in terms of our identity. blematic because it implies that all human beings are responsible

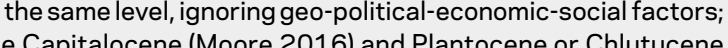
(Haraway 2016) exist as well, among others.

4. Transhackfeminism revolves around experimentation with the body in cons-
tant transformation (trans) and technology (hack) (THF! 2015) Chimera Rosa, 2017; Humalya, by Petric and Sebjanic, 2016; Skotopoesis, by Spela Petric 2015; Becoming with Fungi, by Hammond, Maggic, and Pin, 2017

ganized sharing, organizing, and processing of resources-s as energy, information, or material goods -are often called commonist (as they are dealing with commons), while what they are doing together is accordingly called communing."

8. lbid www.hybridoa.org/marimutare.

According to Marder (2012, 22-24), becoming-plant is a political movement identity human subjectivity the basis of the welf and question lessons of plant life.

\section{REFERENCES}

Anderson, William. 1990. Green Man: The Archetype of Our Oneness with the Earth. San Francisco: Harper.

y llis. 2006. "Green Man Resurrected: An Examination of the Underlying Meanings and Messages of the Re-Emergence of the
Ancient Image of the Green Man in Contemporary. Westert sul Culture". Thesis for Master of Creative Arts, University of the Sunshine Coast, Queensland, Australia.

Austin, Robert, and Lotte Darso. 2006. "A framework for examining the concept of closure in the innovation process". 3rd Art of Man gement and Organisation Conference, 5 - 8 September 2000,
Krakow, Poland. , Jose Miguel. 2007. Euskal Herriaren Mitologia I = Mitologia De
Pueblo Vasco I. Lasarte-Oria: Etor-Ostoa." Barad, Karen, and Adam Kleinman. 2012. "Intra-actions". Mousse 34: 76-81. Barad, Karen. 2014. "Diffracting
Ilax 20:168-187.

TEMES DE DISSENY \#37 and Silke Helfrich. 2015. Patterns of commoning. Amher

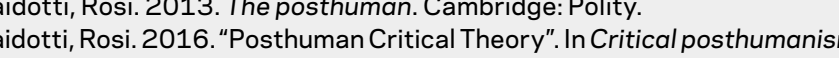
and planetary futures, edited by Debashish Banerji and Makahttps://doi.org/10.1007/978-81-322-3637-5_2

Brassier, Ray. 2008. Nihil Unbound: Naturalism and Anti-Phenomenological

Realism. Basingstoke: Palgrave-Macmillan.
Cachat, Elise, Lenny Nelson, Daniel Sachs, Lucia Bandiera, Alison McDonald,

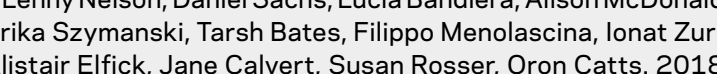
"The Art of Fusion: A Synthetic Approach to Create Cross-King"dom Hybrids". Poster session presented at Fifth Internation ates.

Catts, Oron, and lonat Zurr. 2002. The Tissue Culture and Art Project. https://www.tca.uwa.edu.au/

Chardonnet, Ewan. 2016. "Hypothesis: alien capitalism". Laboratory Plane
$5: 24$.

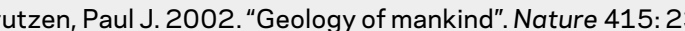

https://doi.org/10.1038/415023a
Crutzen, Paul J. 2016. "Geology of Mankind". In Paul J. Crutzen: A Pioneer on Atmospheric Chemistry and Climate Change in the Anthropo-

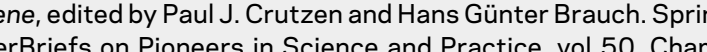
Springer. https://doi.org/10.1007/978-3-319-27460-710

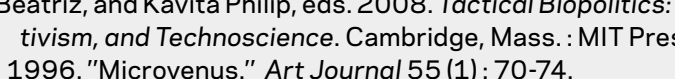
https://doi.org/10.1080/00043249.1996.10791743 lessandro. 2011." "Hacking genomes. The ethics of open and rebel
biology". International Review of Information thics 15.525 .57 . thony, and Fiona Raby. 2013. Speculative everything: Design, fiction, and social dreaming. Cambridge, Mass.: The MIT Press cal Democracy for the Net". In Radical Democracy and the InterLondon: Palgrave Macmillan.

Elfick, Alistair, and Drew Endy. 2014." "Synthetic Biology: What is it and why it and and Drew Endy. 2014. "Synthetic Biology: What is it and why
it matters." In Synthetic Aesthetics: IIvestigating Synthetic
Biology's Designs on Nature. Cambridge, Mass.: The MIT Press.

Ewenstein, Boris, and Jennifer Whyte. 2009. "Knowledge Practices in Design:
The Role of Visual Representations as 'Epistemic Objects".' OrThe Role of Visual Representation ttps://doi.org/10.1177/0170840608083014

a. 2013 [2004]. Calibán y la bruja: Mujeres, cuerpo y acumula-

Frèger, Ción originaria. México: Pez en el árbol.

L London: Thames (2 Hud 2016 “The Green Man The Desire for Deeper Connections We. 2016." "The Green Man: The Desire for Deeper Connections
with Nature."AJE: Australasian Journal of Ecocriticism and Cultural Ecology 6: 21-28

Harding, Mike. 1998. Alittle book of the green man. London: Aurum.
Hayman, Richard. 2010. The Green Man. Oxford: Shire Publications.

Haraway, Donna J.1985. "Manifesto for cyborgs: science, technology, and socialist feminism in the 1980s". Socialist Review $80: 65-108$. and Significant Otherness Chicago : Prickly Pa: Dogs, Preople, Donna J. 2008. When Species Meet. Minneapolis: University of Minnesota Press.

Haraway, Donna J. 2016. Staying with the Trouble: Making Kin in the Chthu-

lucene. Durham: Duke University Press.
Hester, Helen. 2018. Xenofeminismo: Tecnologias de género y politicas de reproducción. Ciudad Autónoma de Buenos Aires: Editorial Caja Negra.

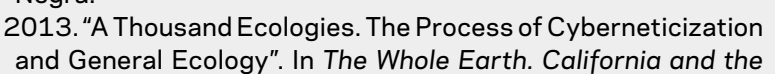
and General Ecology". In The Whole Earth. California and the
Disappearance of the Outside, edited by Diedrich Diederichsen and Anselm Franke, 121-130 Berlin : Sternberg Press.

CÁPSULA ILUSTRADA

100
Hörl, Erich. 2018. The Archaï Illusion of Communication. Amsterdam: Am-

Husserl, Sterdam University Press.

intime du temps Translated bêneménologie de la conscience Universitaires de France.

Kristensen, Stefan. 2017. La Machine Sensible. Paris: Hermann. Kac, Eduardo. 1998. "Transgenic Art". Leonardo Electronic Almanac 6(11)

Keetley, Dawn, and Angela Tenga, eds. 2016. Plant horror. London: Palgrave

Knorr-Cetina, Karin. 2001. "Objectual Practice". In The Practice Turn in Contemporary Theory, edited by Theodore R. Schatzki, Karin Knor

Knorr-Cetina. Karin. 2013, "Culture in global knowledge societies: knowledge cultures and epistemic cultures". Interdisciplinary Science Reviews 22(4): $361-315$.

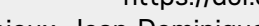

Lajoux, Jean-Dominique. 2016. Fêtes paiennes : les grandes heures du ca-

Latour, Bruno. 2014. "Agency at the Time of the Anthropocene". New Literary

History 45(1): 1-18.
Lorenzo, Vanessa. 2016. "Hybridizations: the role of design in the contex of biotechnology". Master thesis, Haute école d'art et de design,

Llopis, Maria. 2015. Maternidades subversivas. Tafalla: Txalaparta

Marx, Karl. 2011 [1866]. El capital. Librol, Capitulu VI (inédito): Resultados

Miyazaki, Shintaro. 2019."'Take Back the Algorithms! AM Media Theory of Com monistic Affordance". Media Theory 3(1): 269-286.
https://journalcontent.mediatheoryjournal. org/index.php/mt/

Miyazaki, Shintaro, and Susanna Hertrich. 2021. "Following the Elephant-Notance." NERD - New Experimental Research in Design, edited by Michael Erlhoff and Wolfgang Jonas, 82-96. Basel: Birkhäuser. https://doi.org/10.1515/9783035617429-000 and the Crisis of Capitalism.
Myers, William. 2015. Bio Art: Altered Realities. London: Thames \& Hudson

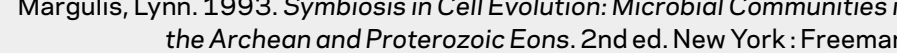
the Archean and Proterozoic Eons. 2nd ed. New York: Freeman,
Marder, Michael. 2012. "Resist like a plant! On the Vegetal Life of Political
Movements". Peace Studies Journal 5(1): 24-32. Special Issue

Movements". Peace Studies Journal $5(1)$ : 24-32. Special lissue
Occupy Movement.
Ortiz-Osés, Andrés. 2007. Los mitos vascos: aproximación hermenéutica

Bilbao: Universidad de Deusto.
Pechblenda. 2014. "tRANS hACK fEMINISt MUTATIONS". Pechblenda Lab. https:///pechblenda.hotglue.me/?transhackfeminism_en
Rheinberger, Hans-Jörg. 1997. Toward a History of Epistemic Things: Synthe sizing Proteins in the Test Tube. Stanford: Stanford University
Press.

Press
Shantz, Jeff. 2013

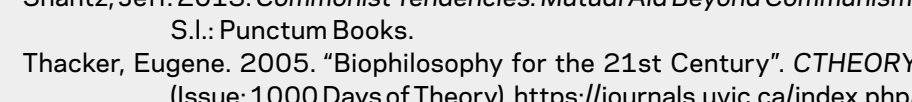
ctheorylarticle/view/14452

THF!. 2015. "Informe del Encuentro TransHackFeminista(THF!)". THF! transhackfeministt. Available at: https://transhackfeminist.noblogs

Tsing, Anna. 2012. "Unruly Edges: Mushrooms as Companion Species". En vironmental Humanities 1 (November): 141-154.
http://www.environmentandsociety.org/node/5415 


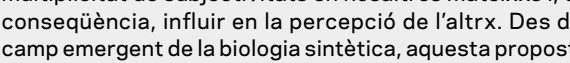

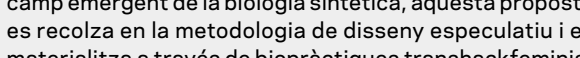

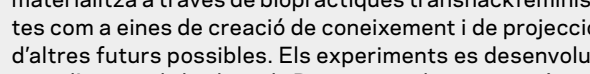
pena entorndel aplaca de eetri com a abjecte epistèm
La placa conté una unió simbioticica de cèl-ulues humanes i vegetals interpenetrant-se, digerint-se i iassinilant-se especieie, gènere, cultura i naturalesa. Mentre es materia

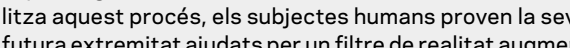
tada (RA), com a proxy de la fisica, per tal de hackejar

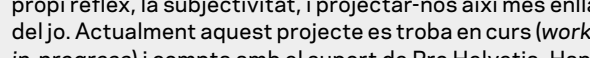
del jo. Actualment aquest projecte es troba en curs (work-
in-progressilicompta amm e l suport de Pro Helevetia, Han-
gar Barcelona (programa Biofriction de la UE), Utopiana

MRIMUTARE: DISSENY ESPECULATIU I PRACTIQUES TRANSHACKFEMINISTES REFER EL (BIO)BÉ COMÚ (BIO-COMMON

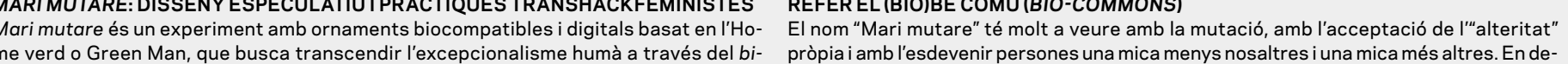

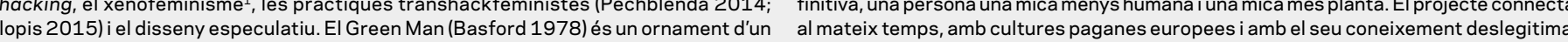

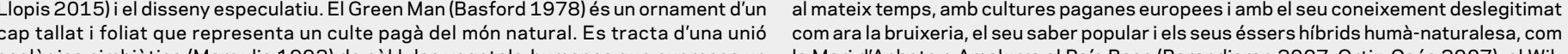

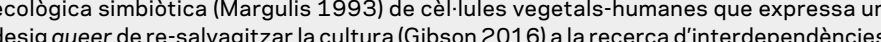
desig queer de re-salvagitzar la cultural (Gibsol
més intimes amb la naturales (I) Freger 20161 .

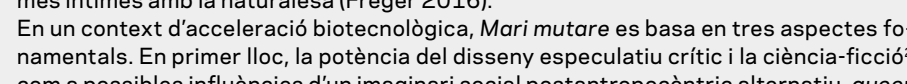

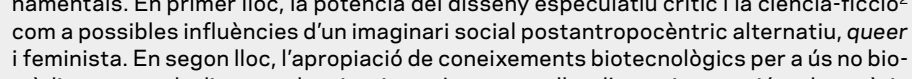

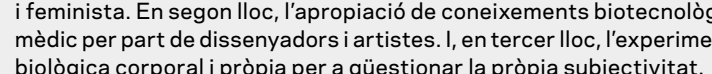

Al'hora de contextualitzar el projecte, cal esmentar que el dissenyy ha abandonat la seva

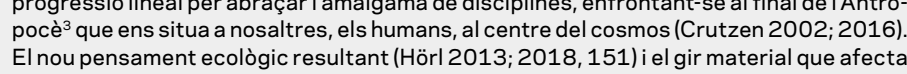

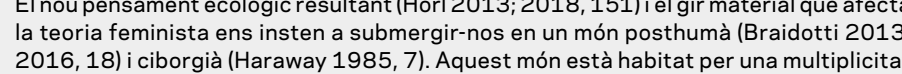

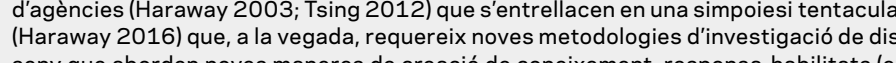

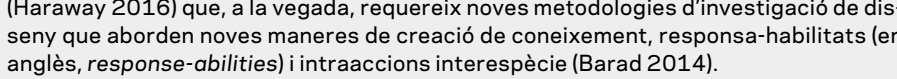

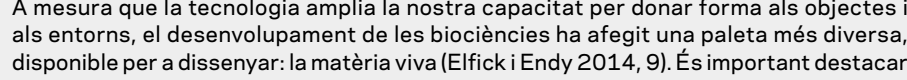

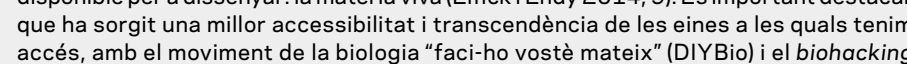

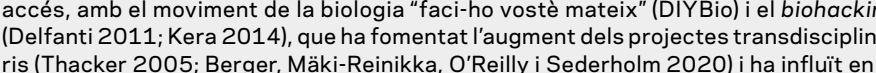
manera en que els sidssenvyadors peninsen, treballen (Lorenzo 2016) i fan investigació de
disseny (Hertrich i Hertrich 2021).

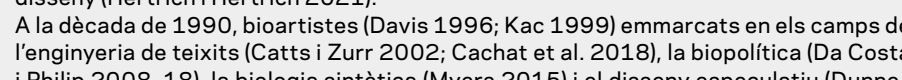

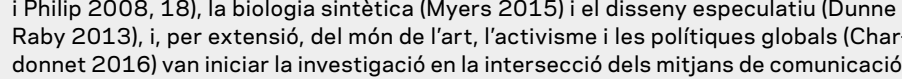

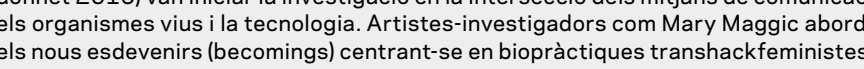

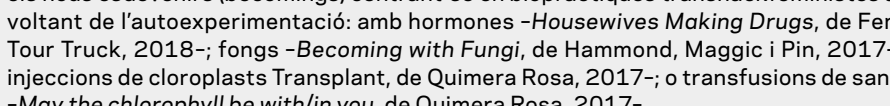

TEMES DE DISSENY \#37

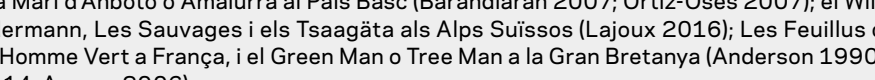
In concret, el Green Man (Basford 1978; Gibson 2016) actua, en certa manera, com
representant de les anteriors figures humà-naturalesa pel simple fet d'estar mol més documentadada La figura, caracteritzada amb plantes enfiladisses travessant-lit C. Al principi era una imatge de culte pagà que més tard va acabar sent apropiada per Església, i les seves representacions van ser especialment nombroses durant 'l'ppoca
medieval (Hardin 1998 ; aun precursor simbolic de l'́brara de diversos artistes contemporanis, els quals tambe

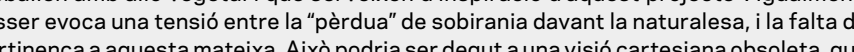

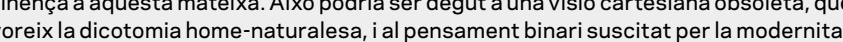

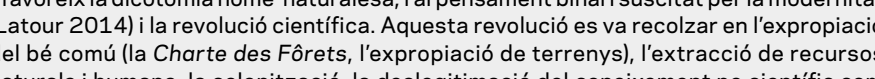

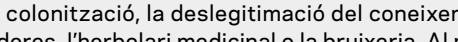
anar acompanyat per la imposició d'una cosmovisió misògina sobre la figura femenina, plicacions biopolitiques

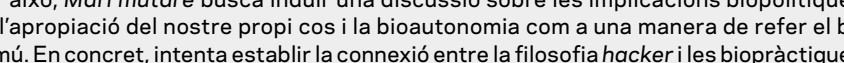

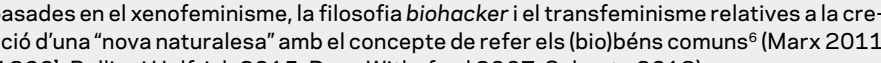

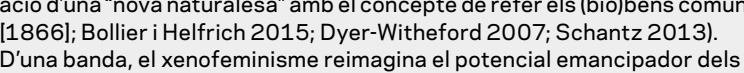

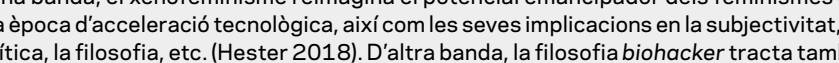
(a) procés d'investigaciós se situa en un delicat equilibri entre léticica de la la manipulació do do

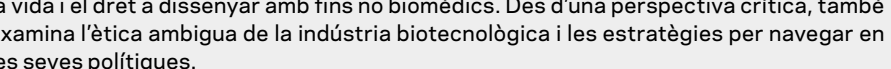
DESCONSTRUINT L'EXCEPCIONALISME HUMA

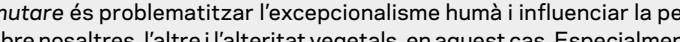

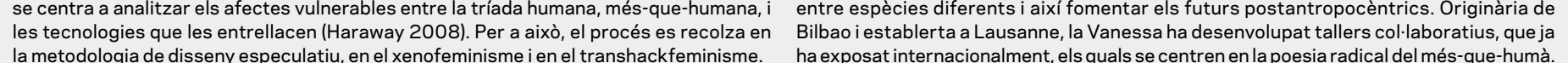

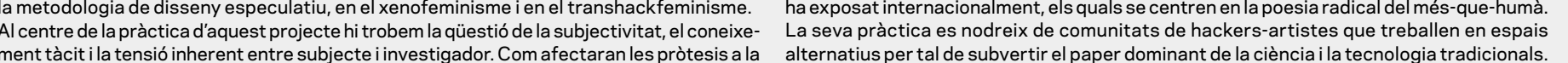

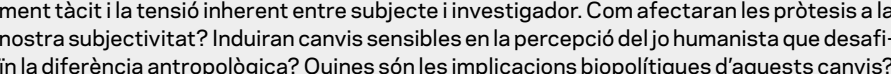
centrada tant en el coneixement tavicit com en les tensions inherents entre el subjecte
investigador i l'objecte epistemic. Aquestes tensions s'aborden des de la fenomenologia La hipotesi del sexperiments estable eix que límplant dicun teixit "alienigena" afectaria

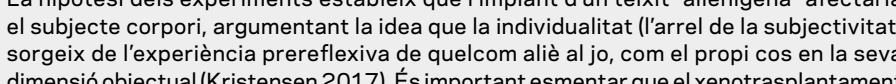

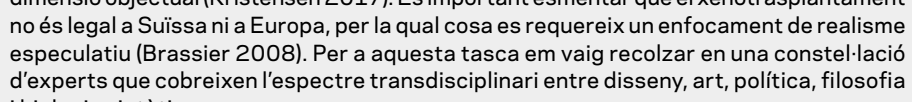

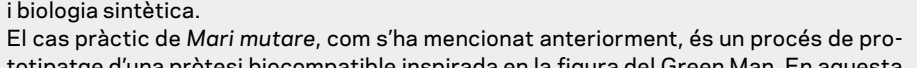
fase s'inclou l'experimentació amb matèria biologgica propioia i aliena. En concret, inclo

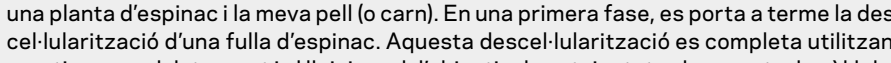
reactius comel detergenti iell lixiciuamb l'objectiu de netejar totes les parets decell-lules
vegetals. Aixi mateix, en aquest moment s'stà provant una alternativa al detergent,

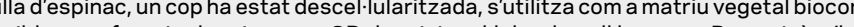

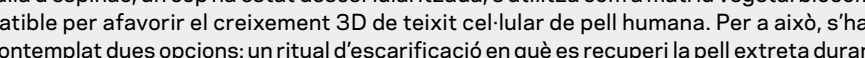
el procés, il a biöpsia. Finalment, Mari mutare comptarà amb la coll-aboració de l'artista

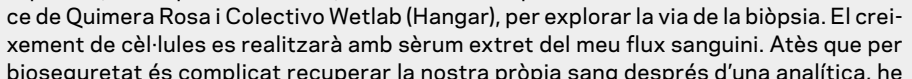

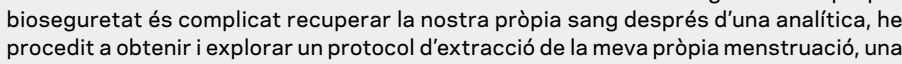

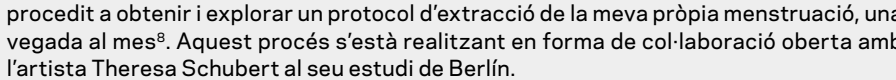

DESPLEGAMENT ONTOLÒGIC: GREEN MAN EN UNA PLACA DE PETRI

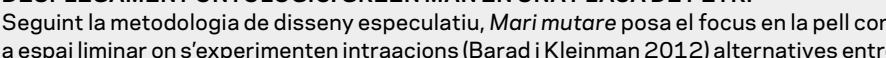

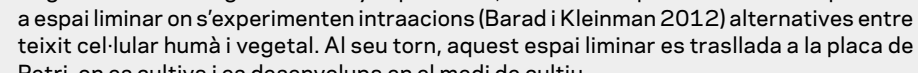

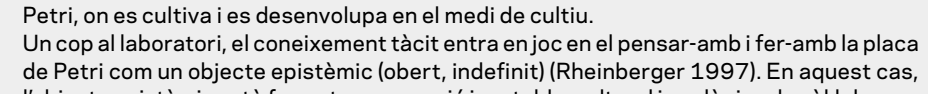

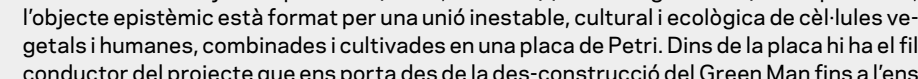
ecologgic-queer de Mari mutare. Per comencar, dins de la la placa de Petri, el ldesplegament
ontologsic del conjunt

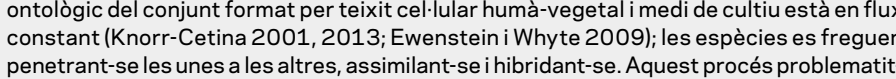

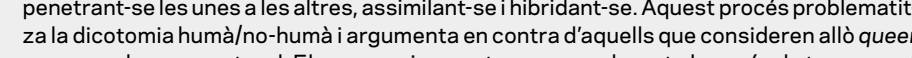

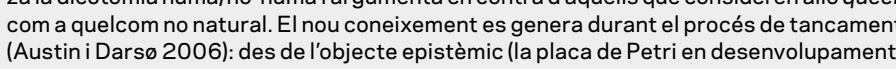

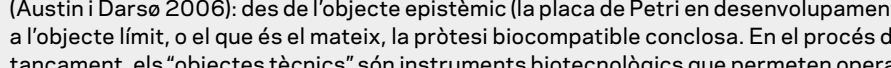

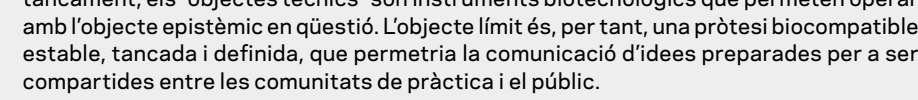

NOTES FINALS

1. Veure, per exemple, el collectiuL Laboria Cuboniks. L
https://monoskopo.orgl/Laboria.Cuboniks

p.org/Laboria Cuboniks

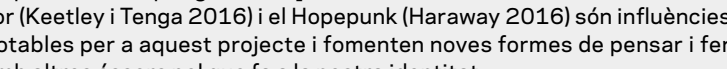

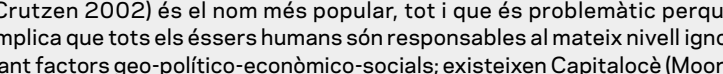

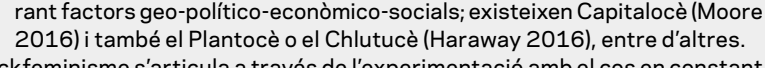

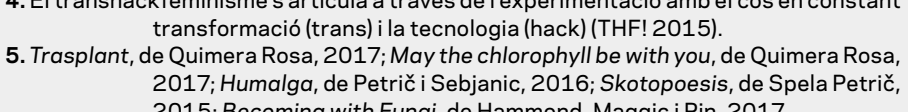

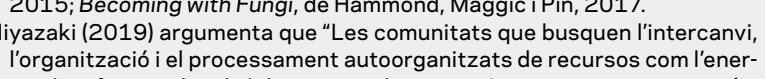

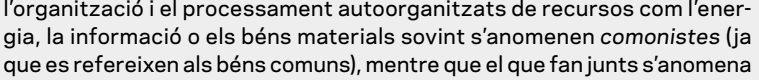
en commoning".
consultant el protocol obert ten procés a la web

8.ldem www.hybridoa.org/marimutare

Jer (2012, 22-24), Esdevenir-planta és un moviment politic que parteix de

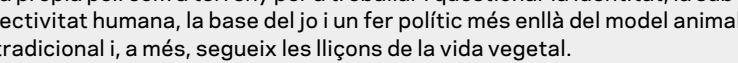

FIGURES

9. 1. Fotomuntatge original de Mari mutare. Vanessa Lorenzo, CC BY-NC-ND.

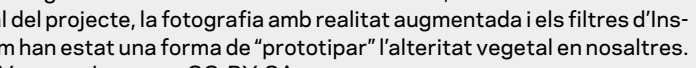

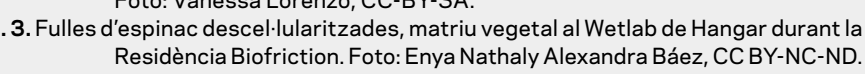

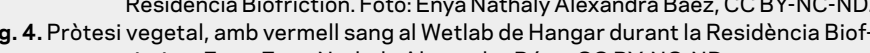

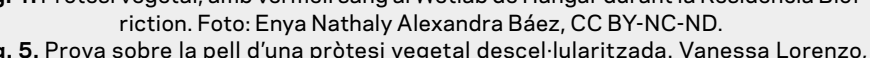
CCBY-NC-ND. Lorenzo, CC CYY-NC-ND.
Fig. 7. Esquema del procés d'investigacio. Vanessa Lorenzo, CC BY-NC-ND.

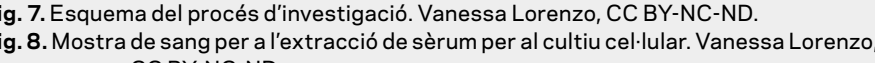
CC BY-NC-ND.
Fig. 9. Fulla perfusionada amb sang humana (de l'autora). Foto: Vanessa Lorenzo, CC-
BY-SA. REFERĖNCIES

CONCLUSIÓ OBERTA

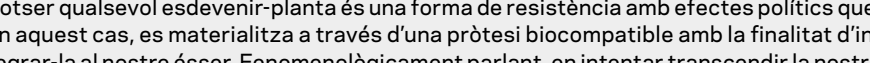
pell més enllà de gènere, especiei o oregne viu, travessem la membrana que separa e ljo $j$.

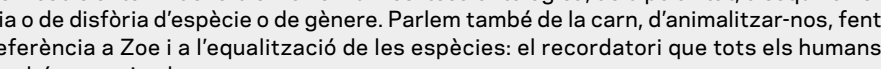
Podriadir-se, aixima

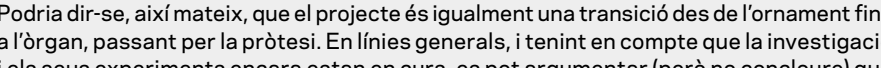
en el procés de crear les prótesisis ja es percecep una alteracaió del cors. L'experiència del

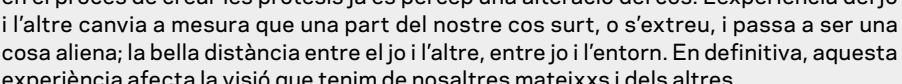

$$
\text { BIOGRAFIA }
$$

Vanessa Lorenzo
Hybridoa, Hackuarium

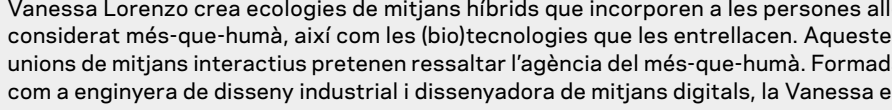

V. LORENZO 

objetos tienen como función abordar elexcepcionalism
humano desde una perssentiva postantropocéntrica, femultiplicidad de subjetividades en nosotrrxs mism $x \mathrm{~s}$ y, consecuencia, influir en la percepción del otrr. Deste el
campo emergente de la biología sintética, esta propuesta

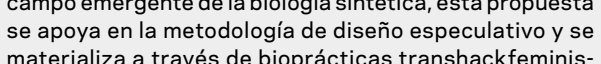
materializa a traveśs de bioprácticas transhackfeminis-
tas como herramientas de creación de conocicimiento y de
proyección de otros futuros posibles. Los experimentos epistémico. La placa contiene un ensamblaie simbiótico

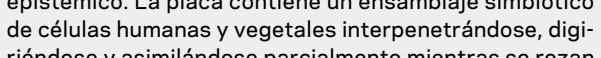

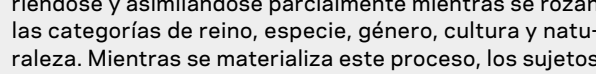
raleza. Mientras se materializa este proceso, los sujetos
humanos prueban su futura extremidad ayudados por un
filtro de realidad aumentada (RA), como proxy de la física,

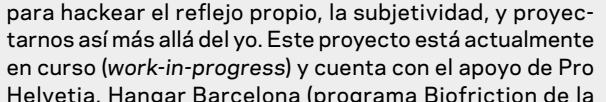
Helvetia, Hangar Barcelona (program,
UE), Utopiana Ginebra y Hackuarium.

MARI MUTARE: DISEÑO ESPECULATIVO Y PRACTICAS TRANSHACKFEMINISTAS REHACER EL (BIO)BIEN COMÚN(BIO-COMMONS

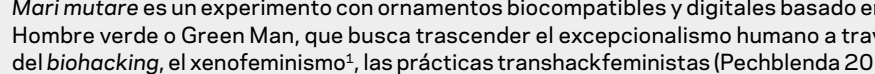

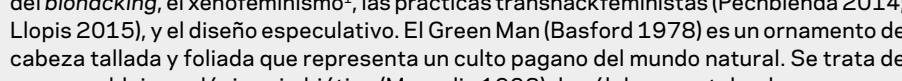
un ensamblaje ecologico simbiético (Margulis 1993$)$ de células vegetales-humanas que
expresasa un deseo queer de re-salvajizar la cultura (Gibson 2016) en busca de interdependencias más intimas con la naturaleza (Frèger 2016).

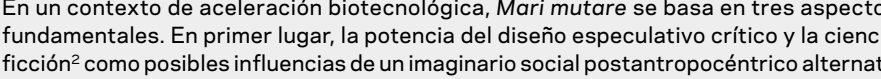

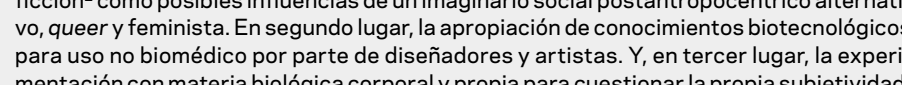

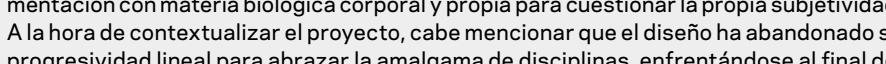

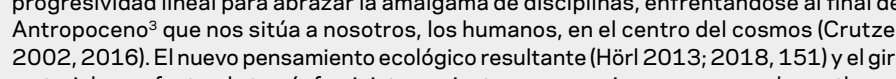
material que afecta a la teoría feminista nos instan a sumergirnos en un mundo posthuma-
no (Braidotti 2013; 2016, 18) y ciborgiano (Haraway 1985, 7). Este mundo estáhabitada

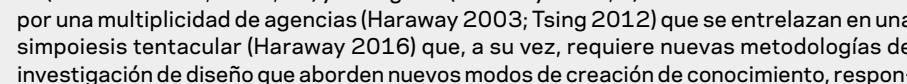

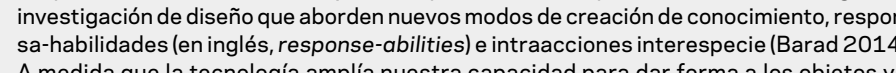

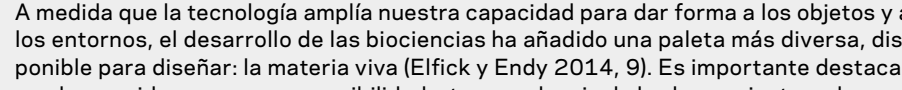

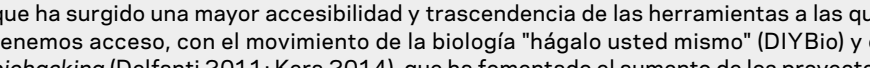

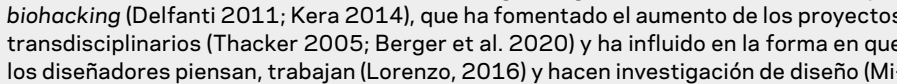

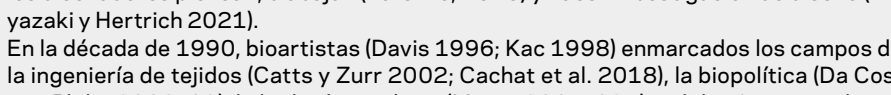

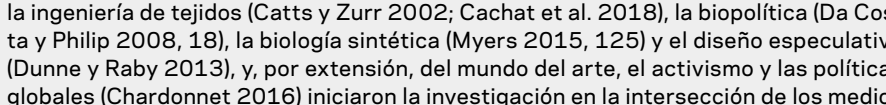

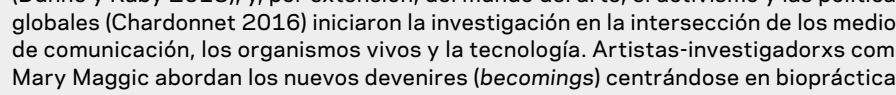

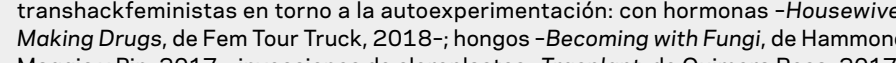

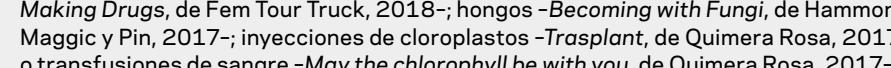

TEMES DE DISSENY \#37

REHACER EL (BIOIBIEN COMÚN (BIO-COMMONS)
Inombre "Mari mutare" tiene mucho que ver con la mutación, con la aceptación de la

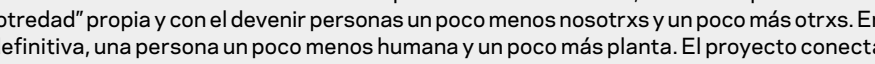

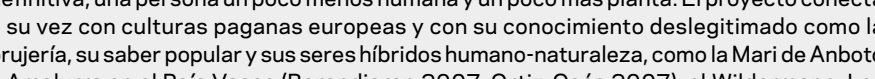

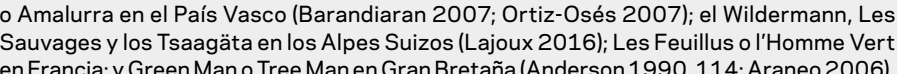

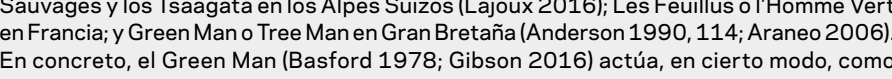

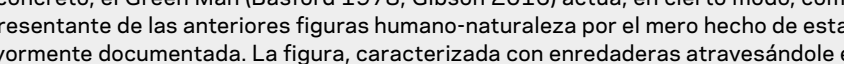

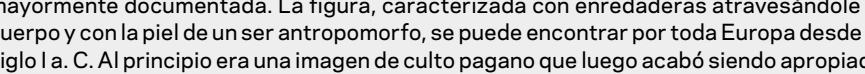
por la I Ilesia, y sus representaciones fueron especialmente numerosas durante la época
medieval ( Hardin 1998; Hayman 2010 ). Este hibrido humano-planta puede verse com precursor simbolicic de la abra de varios artistas contemporáneos, quienes también Wajan con lovegetal y que sirven de inspiración de este proyectos. I I gualmente, el ser

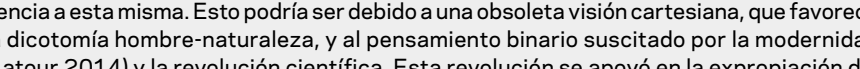

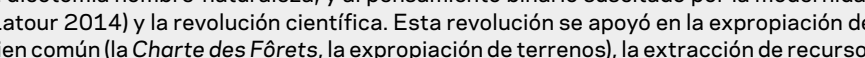
aturales y humanos, la colonización, la deslegitimación del conocimiento no-cientifíico stof fue acompanãado por la i imposicicín de una cosmovisión miscósina sobre la figura a
menina, que consideraba la naturaleza y el cuerpo de la mujer como algo que se pod apropiación de nuestro propioio cuerpoo y y la bioautonomía como una manera de de rehace

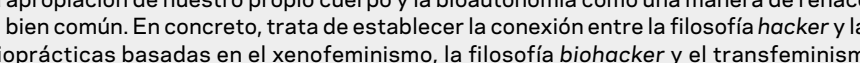
elativas a la creación de una "nueva naturaleza" con el concepto de renacer los
(bio Schantz 2013).

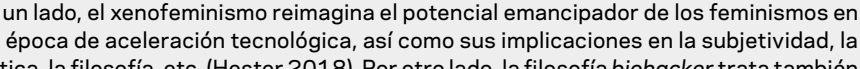

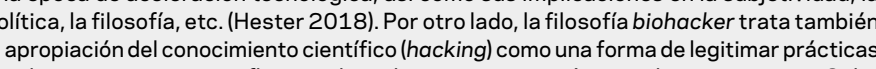
nombrar que todo el processo de investigación se situntáa en un con delicado propio cuuilibrio entre Cab

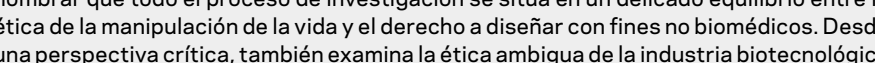
Y

DECONSTRUYENDO EL EXCEPCIONALISMO HUMANO

CÁPSULA ILUSTRADA

104

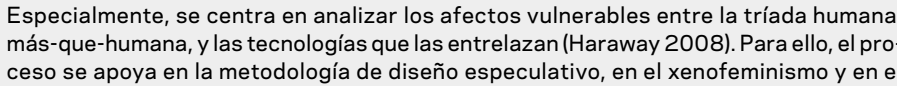

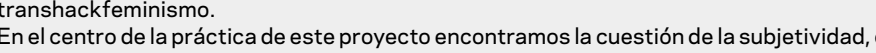

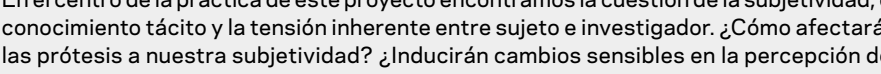
Yohumanista aue desatien la differencia antropolígica? ¿Cuales son las implicaciones
biopoliticas de estos cambios?

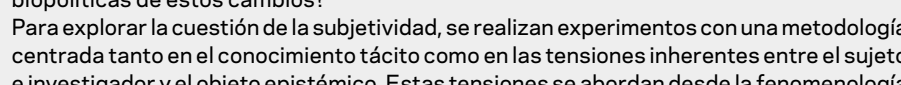

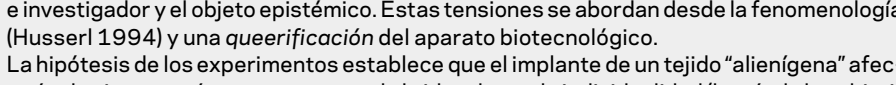

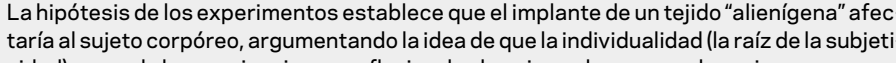
vidad) surge de la experienciap prerrefelexiva dea algo ajeno al yo, comoel propio cuerpo ens
dimensión ojjetual (Kristensen 2017). Es simportante mencionar que el xenotrasplanten Brassier 2008). Para esta tarea me apoyé en una constelación de expertos que cubren El casos práctico de Mari mutare se trata, como se ha mencionalo anterior in mente, dou un proceso de prototipado de una prótesis biocompatible inspirada en la figura del Green
Man. En esta fase se incluye la experimentacíón con materia biológica propia y ajena. En

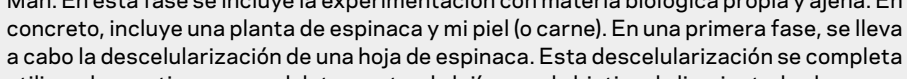

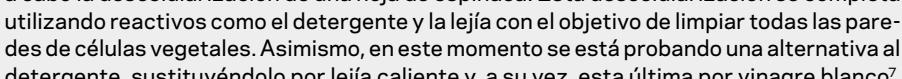

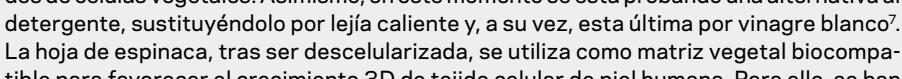
contemplado dos opciones: un ritual de escarificicación donde se receupere la piele extraíd crecimiento de cêlliasse realizará con suero extraído de mi if flujo sangunuineo. Dado que DESPLIEGUE ONTOLÓGICO: GREEN MAN EN UNA PLACA DE PETRI

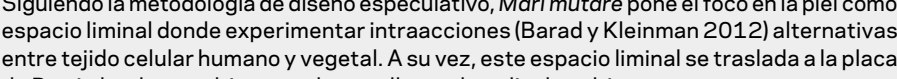

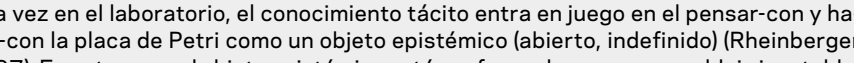

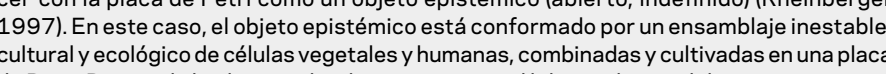

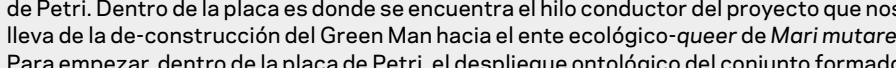

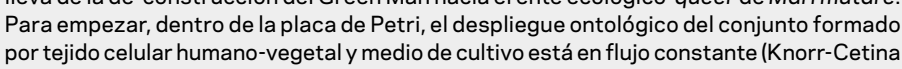

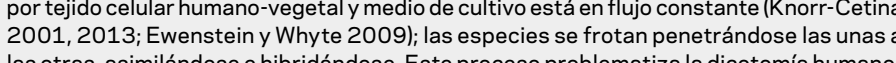

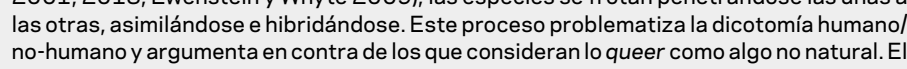

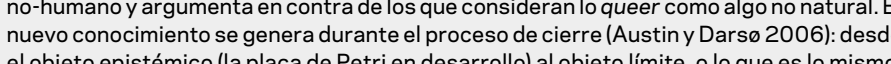
el objeto epistémico (lla placa a de Petrien desarrollol) al objetol limite, olo que es Io mismo,
la prótesis biocompatible concluida. En el proceso de cierre, los "objetos técnicos" son in protesis biocompatible concluida. En el processo de cierre, los "ojetos teecricos" son
instrumtos biotecnologicos que permiten operar con el objeto epistémico en cuestión.

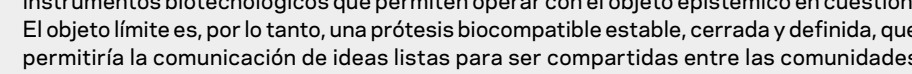
permitiría la comunicaca
de práctica yel publico.

CONCLUSIÓNABIERTA

Quizás todo devenir-planta sea una forma de resistencia con efectos politicos 9 que, en
ese caso, se materializa at través de una prótesis biocompatible con el fin de integrarla a en nuestro ser. Fenpecie oreino vivente travando, al tratatar de trascender nuestra piel más all

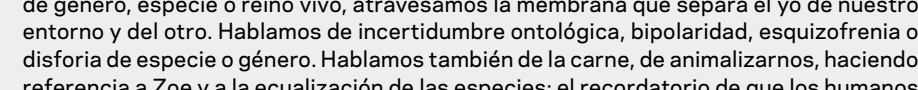

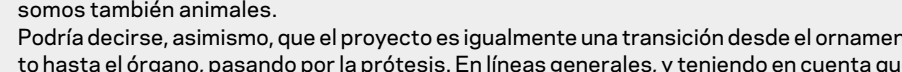

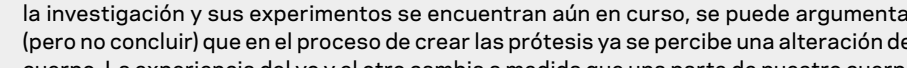

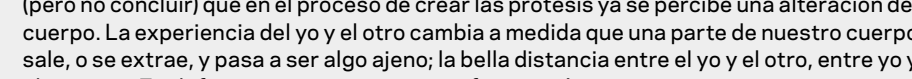
sale, ose extrae, y pasa a ser algo ajeno; la bella distancia entre el yo y el otro, entre yo
el entorno. En definitiva, esta experiencia afecta a cómo nos vemos a nostrtrs mismmo yalxs otrxs.

$$
\begin{gathered}
\text { BIOGRAFíA } \\
\text { Vanssa Lorenzo } \\
\text { Hybridoa, Hackuarium }
\end{gathered}
$$

Vanessa Lorenzo creae ecologias de medios hibridos que incorporan alas personas aquello
considerado más-que-humano, asi como las (biolteconologias que las entrelazan. Estos

V. LORENZO

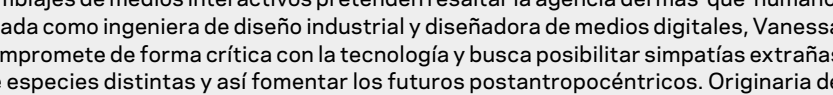

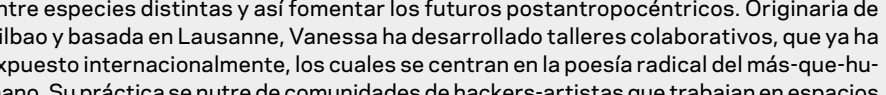

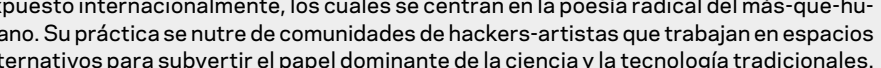

1. Ver por ejemplo el colectivo Laboria Cuboniks. Listado de publicaciones en ror (Keetley Y Tenga 2016) y el Hopepunk (Haraway 2016) son influencias on otros seres en cuanto a nuestra identidad. nivel ignorando factores geos-peres humanos son responsables al misto 2016) entro otros 2016 ) yambién el Plantoceno o el Chlutuceno (Haraway A El transhackfeminismo se articula a través de la experimentación con el cuerpo
constante transformación (trans) y la tecnologia (hack) (THF! 2015).

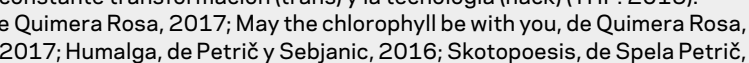
2015; Becoming with Fungl, de Han $200 n d$, Maggic $y$ Pin, 2017 .

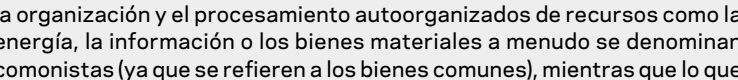
hacen juntos se denomina en commoning".
consultando el protocolo abierto (en procol

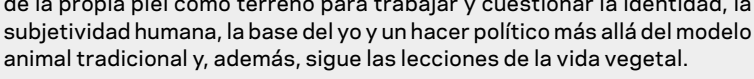

FIGURA

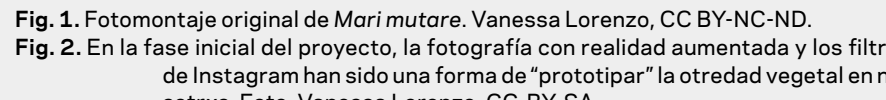
s. Foto: Vanessa L Lorenzzo, CC-BY-SA.

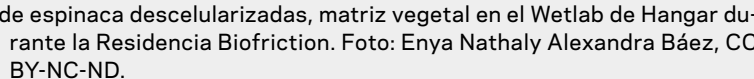
Fig. 4. Prótesis vegetal, con rojo sangre en el Wetlab de Hangar durante la Residencia Fig. 5. Prueba sobre lan piel de una prótesis vegetal descelularizada. Vanessa Lorenzo,

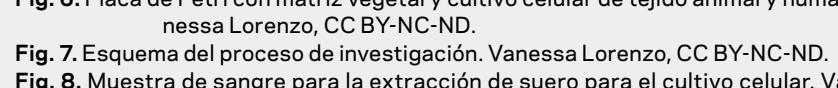

Fig. 9. Hoja perfunszo, C C BY-NC-ND.
Fuctión de suero para el cultivo celilar. Vanessa

REFERENCIAS 